\title{
Too Much of a Good Thing? Gender, 'Concerted Cultivation' and Unequal Achievement in Primary Education
}

\author{
Selina McCoy • Delma Byrne • Joanne Banks
}

Accepted: 30 May 2011 / Published online: 18 June 2011

(C) Springer Science+Business Media B.V. 2011

\begin{abstract}
It is well established that cultural and economic resources imparted to children vary significantly by social class. Literature on concerted cultivation has highlighted the way out-of-school activities can reproduce social inequalities in the classroom. Within this literature however, little attention has been given to the role of gender in concerted cultivation. In this paper, we use data from the first wave of the Growing Up in Ireland longitudinal study to consider how both social class and gender influence the out-ofschool activities of children. Moreover, we examine how out-of-school activities, class and gender impact on children's school engagement and academic achievement. We find that while childrearing logics tend to operate within social class categories, there is an additional cultural aspect of gender in the uptake of different types of out-of-school activities. Our findings suggest the need to move beyond explanations of concerted cultivation to explain gender differences in mathematics and reading attainment.
\end{abstract}

Keywords Social class · Concerted cultivation - Gender - School engagement · Mathematics performance $\cdot$ Reading performance

\section{Introduction}

A key concern in the sociology of education is the intergenerational transmission of social class status from parents to their children. There is now a well established

\footnotetext{
S. McCoy $(\triangle)$

Economic and Social Research Institute, Whitaker Square, Sir John Rogerson's Quay,

Dublin 2, Ireland

e-mail: Selina.McCoy@esri.ie

D. Byrne

Departments of Sociology and Education, National University of Ireland Maynooth (NUIM),

Kildare, Ireland

J. Banks

Economic and Social Research Institute, Dublin, Ireland

e-mail: Joanne.Banks@esri.ie
} 
literature in Ireland and internationally which highlights the relationship between family social class of origin and opportunities and choices that result from differential resources and experiences (see, for example McCoy et al. 2010; Banks et al. 2010; Byrne and Smyth 2010). Cultural analysts of class have now delivered a rich understanding of how cultural resources imparted to children vary by social class in ways that establish inequality at early ages (Bourdieu 1973; Bernstein 1975; Bowles and Gintis 1976; Lareau 2003). In her work, Lareau (2003) identifies the processes through which inequality is reproduced by exploring how parenting and childhood vary by social class. In this work Lareau (2003) conceptualises social class differences in how parents interact with, and determine the time use of, their children. In doing so, she demonstrates striking social class differences in the organisation of children's daily lives, their language development, and their ability to interact with social institutions, with subsequent implications for academic achievement. Within this work, however, there is limited discussion of the role of gender in shaping childhood and framing futures. This paper seeks to address this gap and considers how class and gender influence participation in and the type of out-of-school activities in which children engage. Using a large, nationally representative sample of 9-year-olds in Ireland, we ask whether 'concerted cultivation' is more typical of middle class groups in the Irish context. Furthermore, are females more likely to be engaged in concerted cultivation practices than males? Finally, do concerted cultivation practices help to explain differences in school engagement and academic achievement for girls and boys?

\section{Concerted Cultivation}

Children's educational attainment is strongly associated with the characteristics of their family environment, as the commanding influences of family resources (economic, cultural and social) on children's educational attainment are evident in the strong associations between children's attainment at school and family income, parental occupational status and parental education (Shonkoff and Philips 2000; Smyth et al. 2010). This body of research demonstrates that the resources available to families tend to be limited among some social groups and, in turn, children's educational attainment tends to be poorer among these families. Lareau (2003) argues that the different 'logics' of parenting emerge from, and foster, the re-creation of social stratification through the 'transmission of differential advantages' to children raised within them. In doing so, this work clearly outlines the way in which social class differences emerge through the promotion or 'cultivation' of talents in a concerted fashion among middle class families.

According to the concerted cultivation argument, middle class parents adopt strategies such as parent-child discussion, organised activities and evoke their children's feelings, perceptions, opinions and thoughts. These generally structured, 'enrichment activities' (including after school activities in ballet, drama, tennis, music, swimming and art) are established and controlled by middle-class mothers and fathers and dominate the lives of middle class children (Vincent and Ball 2007). By ensuring that their children have these and other experiences, middle-class parents engage in a process of 'concerted cultivation'. Alternatively, working class 
and low income parents adopt a strategy of the 'accomplishment of natural growth'. Here parents are less involved with the structure of their child's after-school activities and have less focus on how to promote values and skills in their children that will give them an advantage in school. The activities that children from working class families engage in are often less organised and unstructured and children have more free time to play with other children in their local area, with clearer boundaries between adults and children (Lareau 2003).

Concerted cultivation processes, Lareau (2003) argues, create a sense of entitlement in middle class children which plays an important role in institutional settings (schools) where middle class children learn to question adults and address them as relative equals. Because the values and behaviours children learn from a 'cultivated childhood' (discussions with parents, participation in organised activities) are more highly valued in the dominant culture and institutions in society, these children are advantaged in educational and occupational settings. In contrast, the conditions working class and low income children face, and the lessons learned from them, such as an appreciation of unstructured free time and independence from adult-directed activity are less valued in dominant institutions. These children, therefore, develop a sense of constraint, and are disadvantaged in the social system.

While children raised within the 'concerted cultivation' logic are better prepared to achieve within social institutions like school and work, Lareau also outlines downsides to this approach. Middle-class children are generally more stressed and exhausted, less creative, and fight more with siblings than working class or poor children. Others suggest that this type of 'hyper-parenting' (Rosenfeld and Wise 2000), or 'intensive mothering and fathering' (Hays 1996) raise questions about the mental health implications for children subjected to the intense talent development (Tofler et al. 1999; Rosenfeld and Wise 2000). Other studies raise concerns about the transformation of children's time outside of the classroom (Elkind 1981, see also Elkind 2006; Postman 1982) particularly as children are infrequently allowed to play freely in their local area with friends. Academically, this could mean that the 'hurried child' who spends most afternoons and evenings engaged in activities may have less time for homework and suffer stress or exhaustion. Furthermore, if children spend most of their free time engaged in adult organised activities, they may find themselves less able to interact with peers or develop friendships without adult intervention. In essence, Lareau suggests that an over-emphasis on one approach may be detrimental.

The vast body of work on children's out-of-school activities suggests that participation in structured activities, versus free play, is positively associated with children's academic achievement (Marsh and Kleitman 2003; Fletcher et al. 2003; Broh 2002; McNeal 1995; Phillips and Schafer 1971; McCoy et al. forthcoming). Much of the research shows cognitive gains associated with participation in structured out-of-school activities, reflecting the enhancement of a range of cognitive skills, including both literacy and numeracy for example. Some studies also highlight young peoples' orientation towards schooling, with Marsh and Kleitman (2003), for example, highlighting more positive behaviour and less school misconduct among student atheletes in the US context. Broh (2002) also discovered that students who participated in athletics also had a large number of academically orientated friends. This could mean that sports allow students to be in a circle of friends that will help guide them to academic success. 
Further, recent research has found that schools may also awaken children's interest in particular learning activities which they then pursue in their own free time outside school. For example, encountering art or music in school may prompt participation in such activities outside school. While there has been little research on this phenomenon, a recent study by McCoy et al. (forthcoming) highlights how schools with a greater cultural ethos and where students have more opportunities to participate in extra-curricular activities promote greater levels of participation in cultural activities outside school. Further research has also indicated that such activities do not only boost the achievement of individual students but also help to foster a more general sense of ownership over school life. In the Irish context, for example, schools with higher rates of student involvement in extracurricular activities tend to have higher exam performance and student retention rates, all else being equal (Smyth 1999). Further McNeal (1998) found that school based extracurricular activities provide an opportunity for racial and ethnic minorities to access opportunities that will lead to success which they may not have had the chance to experience without the activity.

However, it can also be noted that concerted cultivation has been criticised. Lareau (2003) argues that differences between working class and middle class children's participation in out-of-school activities go beyond access to financial resources, and contends that the lack of activities may also signal a different approach to childrearing that resists the constant demands of developing their children's talents. Instead parents view their role in terms of caring, protecting and loving their children rather than teaching and 'cultivating' them (Gillies 2007). Her work has been criticised for not exploring how and why structural class position leads to each pattern or logic of childrearing (Tiedemann 2005). Tiedemann (2005) argues that the link between parents' own daily experiences of social environments that encourage and promote individual talent is not fully spelled out, thus running the risk of interpretations that parenting logics are natural rather than adaptive and responsive to circumstances. Others have criticised Lareau for not exploring the positive developmental effects of the accomplishment of natural growth.

\subsection{Gender and Concerted Cultivation}

To date, much less attention has been placed on how the gender of the child influences some aspects of parenting, particularly in the context of concerted cultivation. Irish research to date has highlighted the key role of mothers in the education and career choice of their children (O'Hara 1998; McCoy et al. 2006; O'Brien 2007, 2008) with relatively less emphasis on how child rearing goals and parenting styles vary according to gender. Recent research in the Irish context suggests the lack of any significant relationships for child gender in relation to either child or parent behaviour ${ }^{1}$ (Cheevers et al. 2010; Halpenny et al. 2010). However, in other contexts, parent's use of concerted cultivation has been found to be more pronounced among daughters than sons (Cheadle and Amato 2010 in United States).

\footnotetext{
${ }^{1}$ The authors of the report argue that the lack of a significant relationship may be due to the relatively small sample size used or due to the focus of the study which is on a low SES community.
} 
The gendered nature of concerted cultivation has been explained in terms of daughters being more compliant with parental directives and influence than are sons (Power et al. 1994). For this reason, parents may engage in more concerted cultivation with daughters because they are more receptive to parental influence than are sons. Alternative explanations rest on the assumption that parents may feel that more efforts are required to cultivate daughters than sons, because women have traditionally attained lower levels of education and occupational status than males, although this difference has narrowed in recent years (Cheadle and Amato 2010).

The literature on the extra-curricular activities of children and young people also offer insights into gendered concerted cultivation, which suggests that girls tend to engage in structured activities in childhood more than boys (Fletcher et al. 2003) and boys tend to have more freedom in their choice of activities and freedom from supervision (Posner and Vandell 1999). High levels of part-time job holding among Irish males at earlier stages of second-level education have also been explained in these terms (see Byrne 2007), while McCoy and Smyth (2007) find that such parttime employment engagement becomes a zero-sum trade-off with school activities for young people.

\subsection{Educational Attainment}

Gender and educational achievement is a controversial subject in itself (Francis 2009) and, as in other institutional contexts, there is somewhat of a 'gender crisis' in relation to attainment in Ireland (see O'Connor 2007). The gender debate centres largely on the underachievement of boys and has provoked considerable media and policy attention and is increasingly identified as an international issue (see, for example Francis 1999; Francis and Skelton 2005; OECD 2007). However, the gender focus has also been contested (see for example, Epstein et al. 1998; Gorard et al. 1999; Connolly 2006a, 2006b) as analysts have questioned the validity of the focus on gender in educational attainment, arguing that factors such as 'race' and social class have a stronger impact on educational attainment than does gender (Archer and Francis 2007). There is, however, a growing recognition that gender differences in educational attainment in various forms emerge early in life (see, for example, Mensah and Kiernan 2010; Smyth et al. 2010). Studies have shown that gender tends to influence achievement independent of either social class or parental education (see, for example, Smyth et al. 2010). However, little attention has been placed in the Irish context on the extent to which differences between boys and girls in relation to educational attainment systematically vary across social class groups, particularly at primary level. Is there something about the particular combination of gender and social class or gender and family income that tends to reduce or exacerbate further gender differences in educational attainment? We seek to address these questions.

Explanations for gender differences in attainment have ranged from those which assume differences are inherent or biologically determined, to those which argue that differences are socially conditioned or a combination of both biological and social influences (the school culture, teaching practices and the home and wider societal environment). It has been argued that the key influence on educational attainment, family resources (as reflected in the social class and income of the family), has 
different implications for boys' and girls' educational achievement (Connolly 2006a, 2006b; Fischbein 1990; Scarr and Weinberg 1994; Fischbein et al. 1997). This viewpoint argues that gender plays a small role in determining the educational attainment of children whose early education is well supported and structured by parents of higher socio-economic status (SES). However, gender plays a stronger role in shaping the attainment of children of lower SES who are not supported in the same way.

\section{Research Questions and Methodology}

Within this broader concerted cultivation framework, we ask two central research questions:

1. What role do structured and unstructured out-of-school activities play in the school engagement of boys and girls?

2. Does examining the nature of children's out-of-school lives help in understanding gender and social class differences in children's academic achievement?

The paper is based on data from the first wave of the Growing Up in Ireland studythe National Longitudinal Study of Children in Ireland, a nationally representative study of children living in Ireland. Between September 2007 and May 2008, Growing Up in Ireland interviewed 8,578 9-year-old children (representing one-in-seven 9 year old children), their parents and their teachers about a wide range of topics and experiences. The underlying framework of the Growing Up in Ireland study emphasises children's connectedness to the world in which they live. It draws on Bronfenbrenner's perspective (Bronfenbrenner 1979; Bronfenbrenner et al. 2006) which emphasises the importance of considering the multifaceted and multilayered nature of the influences on development over the life course. Crucially the study places central focus on the child's perspective, eliciting their views and experiences on a range of topics including their likes and dislikes, their attitudes towards school and their aspirations. In addition, information is collected from each child's primary caregiver, secondary caregiver, their teacher and other key people in the child's life. Standardised academic tests were also administered to the children. The sample design was based on a two-stage selection process in which the school was the primary sampling unit with the children within school being the secondary units. This design meant that a virtually comprehensive frame of 9-year-old children in Ireland was provided; it allowed for direct access to the children's principal (school head) and teachers (who were key study informants); and it facilitated the self-completion of academic assessment tests in a group setting. Further details on the study are available in Smyth et al. 2010.

\subsection{Variable Description}

In line with the sociology of childhood, children are regarded as active agents in their own educational development (see, for example Corsaro 1997) and so we focus on measures of children's attitudes regarding their schooling as well as their 
academic attainment. Specifically, the paper focuses on children's engagement in school at 9 years of age as measured by their response to the question: 'What do you think about school?', to which the child could respond 'always like it', 'sometimes like it' or 'never like it'. The main focus is on the characteristics of children reporting that they 'never like school', the extent to which boys and girls report such negative feelings towards their school and the association between such views and participation in structured and unstructured out-of-school activities.

The paper then focuses on children's school performance on two standardised tests: a reading test score and mathematics test score. These were measured using standardised reading and mathematics tests (Educational Research Centre 2007a, b). These tests are developed for Irish school children, are linked to the national curriculum and are grade-specific.

In relation to family context, two measures of social background factors were included in the analyses: social class and household income, with the assumption that participation in different types of organised out-of-school activities is likely to be structured by cultural processes and economic resources. The measure of social class used is based on that from the Irish Census of Population, with the occupations included in each group selected in such a way as to bring together people with similar levels of occupational skill. Primary and secondary caregivers are classified into professional workers, managerial and technical workers, non-manual workers, skilled manual workers, semi-skilled manual workers, unskilled manual workers and those where no information is recorded. Household social class was assigned using a dominance criterion, whereby the classification is taken as the higher of the primary and secondary caregiver's class (where the latter is resident). The measure of household income is based on the combined income of the primary and secondary caregivers, with households grouped into income quintiles.

To tap into the educational and cultural resources within the home, we draw on information on access to books in the home, which has been previously found to be a strong predictor of educational performance (Marks et al. 2006). The primary caregiver was asked to report the number of children's books in the home; here we distinguish between fewer than 10 (including none), 10-30 and more than 30 .

We also assess the potential impact of health and social barriers in school engagement and out-of-school activities by including indicators of the presence of an ongoing chronic health problem (according to the child's mother) and the presence of a special educational need. The identification of children with special educational needs is based on the teachers' responses to the following question: 'Do any of the following limit the kind or amount of activity the Study Child can do at school?'

- Physical disability or visual or hearing impairment;

- Speech impairment;

- Learning disability;

- Emotional or behavioural problem (e.g. Attention Deficit (Hyperactivity) Disorder-ADD, ADHD).

Recent research by McCoy and Banks (forthcoming) shows that children with special educational needs are less engaged at school compared to their peers without such needs and face considerable social and academic barriers at school. 
To explore the potential role of differences in the opportunity to engage in different types of out-of-school activities we include a measure of rural versus urban location and travel time to school (low (less than 10 minutes), medium (1020 minutes) and high (20+ minutes)). In the case of the former, one might expect that a wider range of structured activities might be available in urban areas, while children who spend considerable periods of time travelling from school might have less time to participate in out-of-school activities.

A number of questions were asked of children, parents and teachers which relate to the activities of children outside the school setting. In line with previous studies, we make a distinction between activities which are predominately structured in nature and organised/overseen by parents (engagement in cultural activities, membership of clubs) and unstructured, unsupervised time which includes more solitary activities (watching television and playing video-games) and group activities like spending time with friends (Elkind 1981, 2006; Postman 1982; Tofler et al. 1999).

The following activities are examined, all reported by the child's primary caregiver (almost always their mother):

\section{Structured}

- Participation in 'cultural' activities in average week - including dance, ballet, music, arts;

- Membership of a sports club;

- Membership of a youth club, such as scouts, girl guides.

\section{Unstructured}

- Time (hours per day) spent watching television, using a home computer, playing video-games;

- Number of days per week child spends time with friend(s) outside school.

\subsection{Analytical Approach}

The analyses presented in this paper are based on data from the first wave of the Growing Up in Ireland study. As with all cross-sectional data, we acknowledge the need for caution in attributing causality, as the factors are all measured at the same time-point. However, in the models presented, we examine sets of variables which are at least logically, if not temporally, 'prior' to the outcome in focus. For example, parental social class can be considered to be relatively stable over time so we can regard this background factor as influencing children's school performance. Parental educational resources, out-of-school activities and the child's orientation towards school, in contrast, are likely to change and evolve in response to circumstances and so cannot be regarded as causal factors in the same way. However, the analyses do indicate important associations between such factors and children's academic achievement, potentially highlighting the ways in which gender, class and parenting manifest themselves on a day-to-day basis. 
The authors acknowledge that selection effects may be operating, and this represents a potential limitation of the analysis. However, this paper constitutes an important first attempt to examine these issues in the Irish context. Further given that the study is a longitudinal study we will be in the position to test any possible selection bias when the next wave of data, following the sample at the age of 13 years, becomes available next year. At this point we will take account of the factors affecting the likelihood of participating in different types of out-of-school activities and then control for these factors in modelling the effects of different activities on academic outcomes.

Finally, the statistical methodology takes account of the clustering of students within schools, utilising robust standard errors (STATA). This method allows for within-cluster correlation of errors, and results in much more conservative standard errors and smaller t-statistics than those in an unclustered model. That is, this method relaxes the requirement that the errors be independent, by allowing them to be correlated within each cluster group (school).

\section{Results}

Descriptive statistics highlight important gender and social class differences in the out-of-school lives of children and their participation in structured and unstructured activities. $^{2}$ While girls are significantly more likely to participate in cultural activities like music, drama and art, there are also strong variations across social groups (Table 1). For example, while $45 \%$ of boys from professional backgrounds participate in at least one such activity, this is the case for less than one-in-five boys from semi- and unskilled manual backgrounds $(p<.001)$. In the case of membership of sports and activity clubs (like scouts and girl guides), we find that boys are more likely to be members of both types of clubs, across all social classes (Table $2, p<.001$ ). The results also show higher levels of participation in these activities among boys and girls from professional backgrounds. Over four-out-of-five girls from professional backgrounds participate in at least one of these activities; while this is the case for only half of girls from economically inactive households $(p<.001)$. The results clearly show important social class and gender differences in the extent and nature of children's structured out-of-school activities. In many ways we see the reverse patterns when we consider unstructured activities. Table 3 shows the proportion of children spending more than three hours per day watching television, more than one hour a day using their computer and more than one hour per day playing video games. Children from working class and non-employed backgrounds are more likely to watch television for at least three hours per day $(p<.001)$. In terms of video-games, boys are much more likely to spend at least an hour daily engaging in such pursuits, with boys from working class and unemployed backgrounds particularly likely to be in this group $(p<.001)$. Working class children also appear

\footnotetext{
2 The results also show a relationship between participation in structured or organised out-of-school activities and the time children spend travelling from school-with lower levels of participation in cultural activities and clubs among children spending longer periods of time (typically more than 30 minutes per day) travelling home from school.
} 
Table 1 Participation in organised cultural activities (Dance Ballet, Music, Arts etc.) in average week (Mother's Responses)

\begin{tabular}{lccccccr}
\hline & Professional & $\begin{array}{l}\text { Managerial/ } \\
\text { Technical }\end{array}$ & $\begin{array}{l}\text { Non- } \\
\text { Manual }\end{array}$ & $\begin{array}{l}\text { Skilled } \\
\text { Manual }\end{array}$ & $\begin{array}{l}\text { Semi-Unskilled } \\
\text { Manual }\end{array}$ & $\begin{array}{l}\text { Non- } \\
\text { Employed }\end{array}$ & Total \\
\hline Boys & 44.9 & 39.4 & 24.9 & 24.7 & 17.9 & 21.6 & 30.6 \\
Girls & 78.7 & 74.2 & 61.5 & 66.5 & 56.7 & 43.4 & 64.6 \\
Total & 59.3 & 55.7 & 42.5 & 45.0 & 39.6 & 33.2 & 47.3 \\
\hline
\end{tabular}

to spend greater time doing activities with their friends outside school (Table 4): while one third of boys from semi- and unskilled manual backgrounds spend time with their friends 6-7 days of the week, this is the case for less than a quarter of boys from professional backgrounds $(p<.001)$. Further, there is some evidence that boys are given greater freedom than girls to engage in activities with their friends outside school.

\subsection{School Engagement}

Three sets of analyses were conducted to identify the factors associated with disliking school (the whole sample, and the sample of males and females separately). Analyses were conducted adding three successive blocks of variables in a multivariate regression model.

1. Characteristics of the child's social background: social class and household income and cultural resources (number of books);

2. Additional factors which may shape the child's potential or opportunity to engage in different activities (chronic health problems or special educational needs, urban/rural location and travel time from school);

3. Structured organised activities and unstructured activities.

Only final models of each set of analyses are presented in Table 5. This approach allows us to assess the extent to which (a) gender tends to exert an effect on attitudes towards school independent of either social class or parental education and (b) the extent to which differences between boys and girls in relation to attitudes towards school systematically vary across social class groups.

Model 1 of Table 5 presents the results for the whole sample and indicates that boys are substantially more likely than girls to report that they never like school, confirming that gender exerts an effect on attitudes towards school independent of either social class or parental income. Social class differences are not apparent, with the exception of the unknown group which largely comprises unemployed households from which children are more likely to indicate that they never like school. There is also evidence to suggest that children in low income families are somewhat less likely than children from middle income families to report that they never like school, however the differences are slight. Children with special educational needs are significantly more likely than children without special educational needs to report that they never like school (in line with work by McCoy and Banks, forthcoming).

Participation in structured cultural out-of-school activities, even when controlling for social background, is related to school engagement - these children are less likely to 


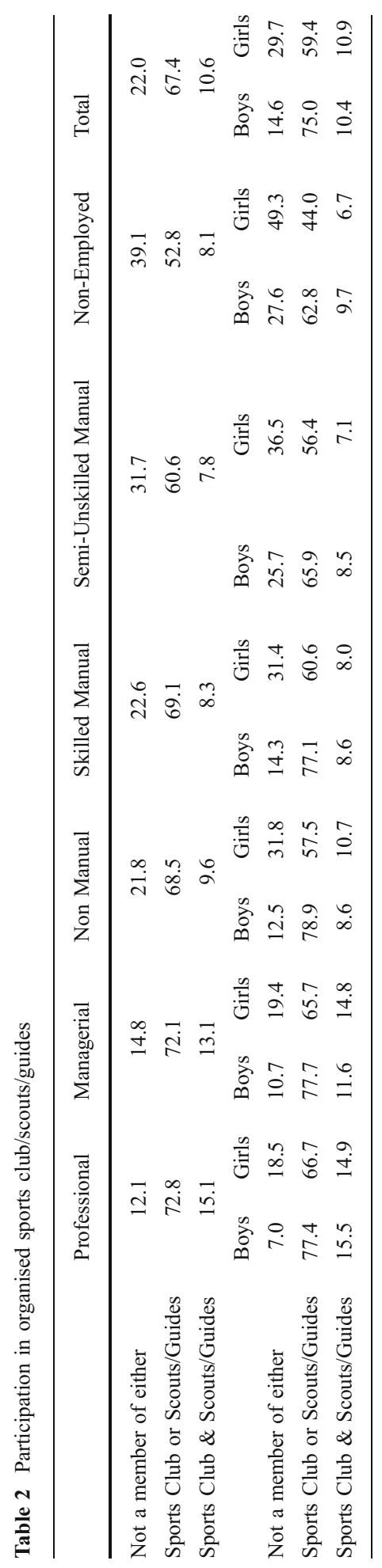




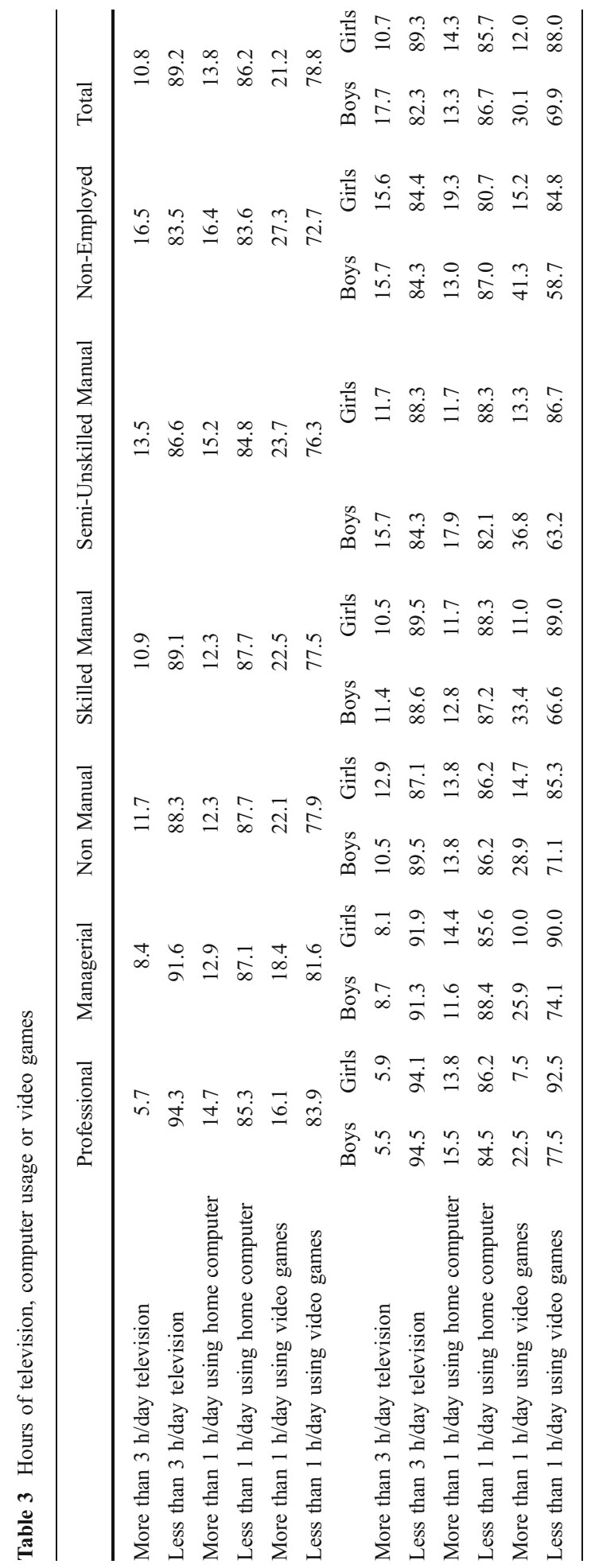




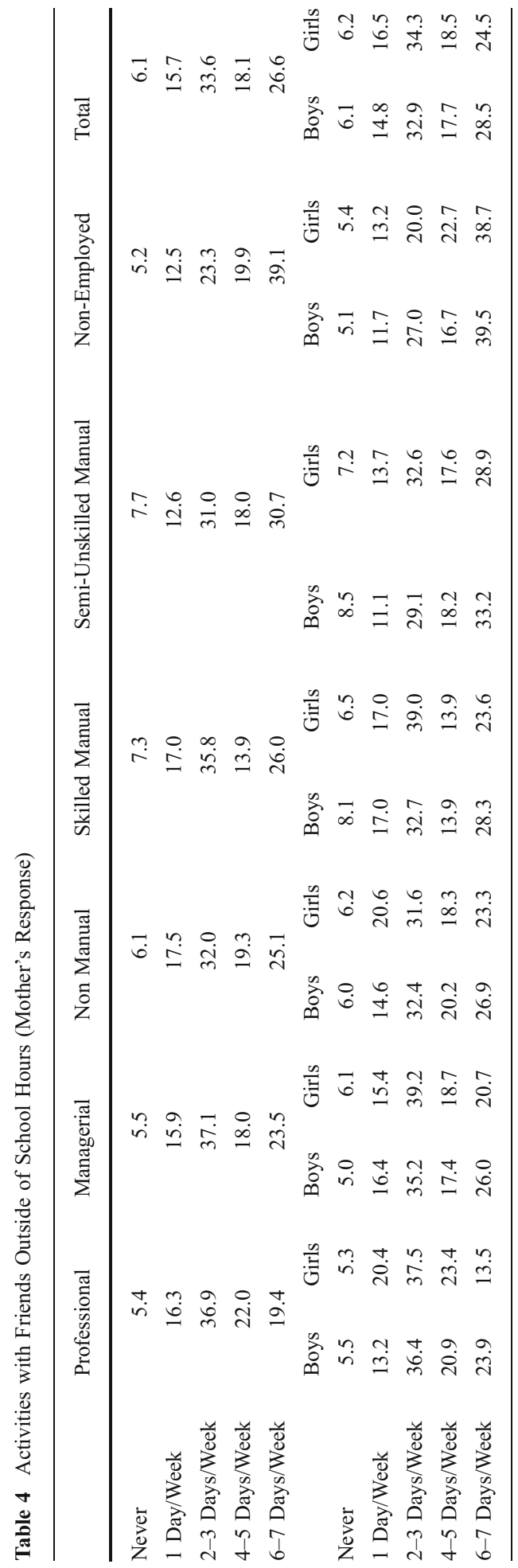


Table 5 Logistic regression model of the factors influencing not liking school among 9 year-old children, robust standard errors

\begin{tabular}{|c|c|c|c|}
\hline & Model 1 & Model 2 & Model 3 \\
\hline & All & Boys & Girls \\
\hline Constant & $-3.364(.222)^{\mathrm{a}}$ & $-2.281(.241)^{\mathrm{a}}$ & $-4.108(.439)^{\mathrm{a}}$ \\
\hline \multicolumn{4}{|l|}{ Gender (Ref: Girls) } \\
\hline Boys & $0.901(.117)^{\mathrm{a}}$ & & \\
\hline \multicolumn{4}{|c|}{ 1. SOCIAL/CULTURAL BACKGROUND } \\
\hline \multicolumn{4}{|c|}{ Social Class (ref: Non-manual) } \\
\hline Professional & $-0.219(.179)$ & $-0.336(.214)$ & $0.217(.346)$ \\
\hline Managerial & $-0.178(.138)$ & $-0.275(.159)$ & $0.154(.274)$ \\
\hline Skilled manual & $-0.040(.167)$ & $-0.067(.196)$ & $0.132(.336)$ \\
\hline Semi- unskilled manual & $0.168(.188)$ & $0.070(.213)$ & $0.449(.377)$ \\
\hline Unknown & $0.666(.198)^{\mathrm{a}}$ & $0.669(.249)^{\mathrm{b}}$ & $0.765(.363)^{\mathrm{c}}$ \\
\hline \multicolumn{4}{|c|}{ Family Income (ref: middle quintile) } \\
\hline Lowest Quintile & $-0.419(.194)^{\mathrm{c}}$ & $-0.743(.229)^{\mathrm{a}}$ & $0.443(.388)$ \\
\hline 2nd Lowest & $0.195(.149)$ & $-0.045(.182)$ & $0.906(.318)^{\mathrm{b}}$ \\
\hline 2nd highest & $-0.039(.154)$ & $-0.052(.179)$ & $0.090(.345)$ \\
\hline Highest & $0.037(.151)$ & $-0.152(.174)$ & $0.652(.316)^{\mathrm{c}}$ \\
\hline Income Missing & $0.405(.176)^{\mathrm{c}}$ & $0.355(.206)$ & $0.692(.404)$ \\
\hline \multicolumn{4}{|c|}{ Children's Books in Home (ref: middle number) } \\
\hline Low & $0.159(.164)$ & $0.274(.186)$ & $-0.318(.424)$ \\
\hline High & $-0.070(.110)$ & $-0.056(.132)$ & $-0.116(.198)$ \\
\hline \multicolumn{4}{|c|}{ 2. OPPORTUNITY/CAPACITY TO ENGAGE IN ACTIVITIES } \\
\hline \multicolumn{4}{|c|}{ Special Educational Need (ref: No SEN) } \\
\hline SEN & $0.401(.131)^{\mathrm{b}}$ & $0.326(.152)^{\mathrm{c}}$ & $0.620(.243)^{\mathrm{c}}$ \\
\hline \multicolumn{4}{|c|}{ Ongoing chronic health problem (ref: None) } \\
\hline Health problem & $0.129(.141)$ & $0.185(.166)$ & $-0.146(.300)$ \\
\hline \multicolumn{4}{|c|}{ Region (Ref: Rural location) } \\
\hline Urban & $-0.078(.105)$ & $-0.108(.121)$ & $0.014(.201)$ \\
\hline \multicolumn{4}{|c|}{ Travel time from school (ref: medium) } \\
\hline Low & $0.089(.115)$ & $0.120(.137)$ & $0.007(.207)$ \\
\hline High & $0.006(.172)$ & $0.004(.209)$ & $0.018(.305)$ \\
\hline
\end{tabular}

\section{STRUCTURED AND UNSTRUCTURED ACTIVITIES}

Structured activities:

Child engages in cultural activities (ref: no)

Yes

Member of sports club/scouts/guides (ref: one)

Child member of both sport club \& scouts/guides etc.

Child not member of either sport club or scouts/guides

Unstructured activities:

Controlled Hours TV, Computer Usage, Video Games 
Table 5 (continued)

\begin{tabular}{|c|c|c|c|}
\hline & Model 1 & Model 2 & Model 3 \\
\hline More than $3 \mathrm{~h} /$ day TV & $-0.127(.164)$ & $-0.308(.213)$ & $0.318(.256)$ \\
\hline $\begin{array}{l}\text { More than } 1 \mathrm{~h} / \text { day using home } \\
\text { computer }\end{array}$ & $0.126(.137)$ & $0.080(.165)$ & $0.211(.236)$ \\
\hline More than $1 \mathrm{~h}$ /day video games & $0.300(.113)^{\mathrm{b}}$ & $0.285(.126)^{\mathrm{c}}$ & $0.330(.251)$ \\
\hline \multicolumn{4}{|c|}{ Activities with friends: (ref: $2-3$ days/week) } \\
\hline Never/1 day/week & $0.018(.129)$ & $0.119(.156)$ & $-0.224(.248)$ \\
\hline 4-5 days/week & $-0.162(.146)$ & $-0.046(.161)$ & $-0.439(.281)$ \\
\hline 6-7 days/week & $0.083(.131)$ & $0.031(.149)$ & $0.220(.237)$ \\
\hline $\mathrm{N}$ & $\begin{array}{l}8,566 \text { pupils in } 898 \\
\text { schools }\end{array}$ & $\begin{array}{l}\text { 4,162 pupils in } 741 \\
\text { schools }\end{array}$ & $\begin{array}{l}\text { 4,402 pupils in } 724 \\
\text { schools }\end{array}$ \\
\hline $\mathrm{Chi}^{2}$ & $220.06^{\mathrm{a}}$ & $83.32^{\mathrm{a}}$ & $65.95^{\mathrm{a}}$ \\
\hline Pseudo $\mathrm{R}^{2}$ & .057 & .033 & .039 \\
\hline
\end{tabular}

${ }^{\mathrm{a}} p<.001,{ }^{\mathrm{b}} p<.01,{ }^{\mathrm{c}} p<.05$

report that they never like school. However, there is no effect of club membership (or non-membership) on disliking school. In terms of unstructured out-of-school activities, while there is no effect of time spent on television viewing, computer usage or activities with friends on disliking school, children who spend more than one hour per day on video games are more likely to report that they dislike school.

For the most part, these patterns hold for both males and females (Models 2, 3 of Table 5). However, boys living in low income families are significantly less likely to report that they dislike school than boys from middle income families. On the other hand, females from moderately low income families and high income families are more likely to report that they dislike school than girls from middle income families. The effect of having a special educational need on school engagement is stronger for females than males, all else being equal.

There are also differences in the influence of structured out-of-school activities on school engagement for males and females. Participation in cultural activities has a significant and positive effect on school engagement for males which is not evident among females. Thus, while boys are less likely to participate in such cultural activities, those who do partake in such pursuits are significantly more likely to be positively oriented towards their schooling.

\subsection{Attainment}

As before, three sets of analyses were conducted to determine the factors associated with reading and mathematics test scores (the whole sample, and the sample of males and females separately). Analyses were conducted adding four successive blocks of variables in a multivariate regression model. The first block of variables relates to social and cultural background, the second to chronic health difficulties, special educational needs and regional variables; and the third which relates to structured and unstructured out-of-school activities. In addition, we include the measure of whether the child likes school, as utilised in the earlier model, as a 
measure of school engagement. Only final models of each set of analyses are presented in Tables 6 and 7.

\subsection{Reading Scores}

Model 1 in Table 6 indicates that boys achieve higher average reading scores than girls, when controlling for social composition and out-of-school activities. Clear differences are evident in reading scores across social class and family income groups. Controlling for household income, children from professional and managerial social class backgrounds achieve significantly higher reading scores than those from non-manual social backgrounds, while children from skilled manual backgrounds achieve significantly lower reading scores than those from non-manual social backgrounds. Controlling for social class, household income is clearly predictive of children's reading attainment with substantial gaps evident between those from high income and low income families. While children from low income families have significantly lower reading scores than those from middle income families, children from high income families have significantly higher reading scores than those from middle income families. It would appear that social class and family income have additive effects on children's reading attainment. When educational and cultural resources within the home are added to the model, in keeping with previous research (Marks et al. 2006; Smyth et al., 2010) the number of books in the home is a good predictor of positive educational outcomes. Children with special educational needs have significantly lower reading scores than those without such learning needs. Geographic region also exerts an influence on reading scores as children living in urban areas achieving significantly higher reading scores than children living in rural areas.

When we consider the relationship between structured out-of-school activities and academic achievement in reading we find that children who take part in cultural activities outside school also achieve higher reading scores, again in keeping with Irish and international research (Bodovski and Farkas, 2008; McCoy et al., forthcoming). Interestingly, there is also an effect of club membership, indicating that some club membership is more beneficial than none, while multiple membership is most beneficial. In terms of unstructured out-of-school activities, there is no effect of time spent watching television, using a home computer or playing video-games. However, children who spend extensive amounts of time with friends have significantly lower reading scores than children who spend smaller amounts of time with friends. Finally, in the final block, children who are highly disengaged from school, indicating that they never like school, have significantly lower reading scores than children who like school.

For the most part, these patterns hold for both males and females (Models 2, 3 of Table 6), as social, cultural and economic resources operate in the same way for males and females in terms of reading attainment. The main differences emerge in relation to the influence of time spent in activities out-of-school. For boys and girls there is an effect of structured and unstructured activities on reading attainment. However, the effects of different types of structured activities differ for boys and girls. For boys, there is no effect of club membership on reading attainment while for girls there is a clear positive effect of such membership. That is, girls who are not 
Table 6 OLS Regression model of the factors influencing reading test performance among 9 year-old children, robust standard errors

\begin{tabular}{lccc}
\hline & All & Boys & Girls \\
\hline $\begin{array}{l}\text { Constant } \\
\text { Gender (Ref: Girls) }\end{array}$ & $-0.126(.046)^{\mathrm{b}}$ & $-0.058(.060)$ & $-0.110(.061)$ \\
Boys & & & \\
\hline
\end{tabular}

1. SOCIAL/CULTURAL BACKGROUND

Social Class (ref: Non-manual)

\begin{tabular}{|c|c|c|c|}
\hline Professional & $0.288(.034)^{\mathrm{a}}$ & $0.320(.048)^{\mathrm{a}}$ & $0.254(.049)^{\mathrm{a}}$ \\
\hline Managerial & $0.127(.028)^{\mathrm{a}}$ & $0.167(.042)^{\mathrm{a}}$ & $0.088(.035)^{\mathrm{c}}$ \\
\hline Skilled manual & $-0.130(.034)^{\mathrm{a}}$ & $-0.093(.050)^{\mathrm{c}}$ & $-0.163(.045)^{\mathrm{a}}$ \\
\hline Semi- unskilled manual & $-0.064(.039)$ & $-0.079(.060)$ & $-0.053(.050)$ \\
\hline Unknown & $-0.009(.052)$ & $-0.078(.078)$ & $0.050(.069)$ \\
\hline \multicolumn{4}{|c|}{ Family Income (ref: middle quintile) } \\
\hline Lowest Quintile & $-0.157(.038)^{\mathrm{a}}$ & $-0.108(.057)^{\mathrm{c}}$ & $-0.193(.050)^{\mathrm{a}}$ \\
\hline 2nd Lowest & $-0.015(.034)$ & $-0.050(.051)$ & $0.015(.046)$ \\
\hline 2nd highest & $0.093(.031)^{\mathrm{b}}$ & $0.091(.044)^{\mathrm{c}}$ & $0.094(.043)^{\mathrm{c}}$ \\
\hline Highest & $0.141(.032)^{\mathrm{a}}$ & $0.116(.046)^{\mathrm{c}}$ & $0.165(.046)^{\mathrm{a}}$ \\
\hline Family Income missing & $0.074(.044)$ & $0.088(.061)$ & $0.059(.063)$ \\
\hline \multicolumn{4}{|c|}{ Children's Books in Home (ref: middle number) } \\
\hline Low & $-0.239(.037)^{\mathrm{a}}$ & $-0.234(.050)^{\mathrm{a}}$ & $-0.254(.057)^{\mathrm{a}}$ \\
\hline High & $0.273(.023)^{\mathrm{a}}$ & $0.253(.034)^{\mathrm{a}}$ & $0.292(.030)^{\mathrm{a}}$ \\
\hline
\end{tabular}

2. OPPORTUNITY/CAPACITY TO ENGAGE IN ACTIVITIES

Special Educational Need (ref: no SEN)

\begin{tabular}{|c|c|c|c|}
\hline SEN & $-0.855(.034)^{\mathrm{a}}$ & $-0.862(.047)^{\mathrm{a}}$ & $-0.856(.050)^{\mathrm{a}}$ \\
\hline \multicolumn{4}{|c|}{ Ongoing chronic health problem (ref: none) } \\
\hline Health problem & $-0.020(.035)$ & $0.022(.048)$ & $-0.067(.049)$ \\
\hline \multicolumn{4}{|c|}{ Region (Ref: rural location) } \\
\hline Urban & $0.095(.029)^{\mathrm{b}}$ & $0.111(.040)^{\mathrm{b}}$ & $0.080(.037)^{\mathrm{c}}$ \\
\hline \multicolumn{4}{|c|}{ Travel time from school (ref: medium) } \\
\hline Low & $0.012(.023)$ & $0.010(.031)$ & $0.011(.031)$ \\
\hline High & $-0.001(.038)$ & $0.084(.052)$ & $-0.085(.051)$ \\
\hline
\end{tabular}

3. STRUCTURED AND UNSTRUCTURED ACTIVITIES

Structured activities:

Child engages in cultural activities (ref: no)

Yes

$0.142(.022)^{\mathrm{a}}$

$0.135(.033)^{\mathrm{a}}$

$0.148(.030)^{\mathrm{a}}$

Member of sports club/scouts/guides (ref: one)

Child member of both sport

$0.064(.030)^{\mathrm{c}} \quad 0.061(.047)$

$0.068(.041)$

club \& scouts/guides etc.

Child not member of either sport

$-0.083(.027)^{\mathrm{b}} \quad-0.060(.045)$

$-0.088(.034)^{\mathrm{b}}$ club or scouts/guides

Unstructured activities:

Controlled Hours TV, Computer Usage, Video Games

More than $3 \mathrm{~h}$ /day TV

$0.000(.035)$

$-0.004(.051)$

$0.000(.045)$ 
Table 6 (continued)

\begin{tabular}{lccc}
\hline & All & Boys & Girls \\
\hline $\begin{array}{l}\text { More than 1 h/day using } \\
\text { home computer }\end{array}$ & $0.045(.029)$ & $0.063(.043)$ & $0.028(.039)$ \\
More than 1 h/day video games & $-0.018(.026)$ & $-0.046(.032)$ & $0.034(.043)$ \\
Activities with friends: (ref: 2-3 days/week) & $-0.010(.027)$ & $-0.052(.041)$ & $0.016(.036)$ \\
Never/1 day/week & $0.031(.030)$ & $-0.008(.043)$ & $0.063(.038)$ \\
4-5 days/week & $-0.103(.027)^{\mathrm{a}}$ & $-0.068(.038)$ & $-0.149(.038)^{\mathrm{a}}$ \\
6-7 days/week & $-0.283(.043)^{\mathrm{a}}$ & $-0.255(.051)^{\mathrm{a}}$ & $-0.335(.070)^{\mathrm{a}}$ \\
School Engagement (ref: likes school) & 8,354 pupils in & 4,051 pupils in & 4,303 pupils in \\
Never likes school & 881 schools & 732 schools & 714 schools $^{\mathrm{a}}$ \\
$\mathrm{N}$ & .210 & .215 & .211 \\
Pseudo $\mathrm{R}^{2}$ & & & \\
\hline
\end{tabular}

${ }^{\mathrm{a}} p<.001,{ }^{\mathrm{b}} p<.01,{ }^{\mathrm{c}} p<.05$

club members have lower reading scores than girls who are members of one club, while girls who are members of two clubs have significantly higher $(p<.10)$ reading scores than girls who are members of one club.

\subsection{Mathematics Scores}

A similar set of models was conducted using mathematics test attainment as an outcome (Table 7). The findings in relation to mathematics are broadly similar to those for reading so will focus only on the distinctive features. Clearly, among all students, there is greater social differentiation in mathematics attainment than in reading attainment. We see that children from professional and managerial backgrounds achieve significantly higher mathematics scores than children from non-manual backgrounds, while children from skilled manual and semi-unskilled manual backgrounds achieve significantly lower mathematics scores than children from non-manual backgrounds. As with reading scores, household income is clearly predictive of children's mathematics attainment with substantial gaps evident between those from high income and low income families.

In terms of structured out-of-school activities, children who take part in cultural activities outside school also achieve higher mathematics scores, again in keeping with the literature. Interestingly, the relationship between club membership and mathematics scores is similar to that found for reading. Children who are not members of either sports clubs or youth clubs have significantly lower mathematics scores than children who are members of one club. This suggests that participation in (a wide range of) clubs/structured activities has a positive impact on schoolwork. The patterns differ somewhat in relation to unstructured activities. Children who spend more than 3 hours a day watching television have lower mathematics scores than children who spend less time watching television. Conversely, children who spend more than 1 hour per day using a home computer achieve higher mathematics scores than those spending less than an hour a day using their computer. It would 
Table 7 OLS Regression model of the factors influencing mathematics test performance among 9 yearold children, robust standard errors

\begin{tabular}{|c|c|c|c|}
\hline & All & Boys & Girls \\
\hline Constant & $-0.814(.045)^{\mathrm{a}}$ & $-0.665(.060)^{\mathrm{a}}$ & $-0.773(.057)^{\mathrm{a}}$ \\
\hline \multicolumn{4}{|l|}{ Gender (Ref: Girls) } \\
\hline Boys & $0.197(.027)^{\mathrm{a}}$ & & \\
\hline \multicolumn{4}{|c|}{ 1. SOCIAL/CULTURAL BACKGROUND } \\
\hline \multicolumn{4}{|c|}{ Social Class (ref: Non-manual) } \\
\hline Professional & $0.220(.034)^{\mathrm{a}}$ & $0.252(.050)^{\mathrm{a}}$ & $0.185(.046)^{\mathrm{a}}$ \\
\hline Managerial & $0.097(.028)^{\mathrm{a}}$ & $0.132(.041)^{\mathrm{a}}$ & $0.063(.036)$ \\
\hline Skilled manual & $-0.094(.032)^{\mathrm{b}}$ & $-0.113(.049)^{\mathrm{b}}$ & $-0.078(.042)$ \\
\hline Semi- unskilled manual & $-0.104(.039)^{\mathrm{b}}$ & $-0.127(.056)^{\mathrm{c}}$ & $-0.089(.053)$ \\
\hline Unknown & $-0.082(.052)$ & $-0.117(.076)$ & $-0.055(.066)$ \\
\hline \multicolumn{4}{|c|}{ Family Income (ref: middle quintile) } \\
\hline Lowest Quintile & $-0.111(.036)^{\mathrm{b}}$ & $-0.108(.054)^{\mathrm{c}}$ & $-0.112(.049)^{\mathrm{c}}$ \\
\hline 2nd Lowest & $0.008(.033)$ & $0.034(.051)$ & $-0.014(.043)$ \\
\hline 2nd highest & $0.061(.030)^{\mathrm{c}}$ & $0.057(.043)$ & $0.068(.042)$ \\
\hline Highest & $0.105(.031)^{\mathrm{a}}$ & $0.115(.045)^{\mathrm{c}}$ & $0.098(.042)^{\mathrm{c}}$ \\
\hline Family Income missing & $0.037(.042)$ & $0.102(.065)$ & $-0.027(.056)$ \\
\hline \multicolumn{4}{|c|}{ Children's Books in Home (ref: middle number) } \\
\hline Low & $-0.174(.036)^{\mathrm{a}}$ & $-0.203(.050)^{\mathrm{a}}$ & $-0.125(.056)^{\mathrm{c}}$ \\
\hline High & $0.129(.021)^{\mathrm{a}}$ & $0.122(.032)^{\mathrm{a}}$ & $0.137(.027)^{\mathrm{a}}$ \\
\hline \multicolumn{4}{|c|}{ 2. OPPORTUNITY/CAPACITY TO ENGAGE IN ACTIVITIES } \\
\hline \multicolumn{4}{|c|}{ Special Educational Need (ref: no SEN) } \\
\hline SEN & $-0.705(.033)^{\mathrm{a}}$ & $-0.728(.045)^{\mathrm{a}}$ & $-0.665(.049)^{\mathrm{a}}$ \\
\hline \multicolumn{4}{|c|}{ Ongoing chronic health problem (ref: none) } \\
\hline Health problem & $-0.055(.032)$ & $-0.041(.043)$ & $-0.070(.049)$ \\
\hline \multicolumn{4}{|c|}{ Region (Ref: rural location) } \\
\hline Urban & $0.060(.029)^{\mathrm{c}}$ & $0.076(.039)^{\mathrm{c}}$ & $0.048(.035)$ \\
\hline \multicolumn{4}{|c|}{ Travel time from school (ref: medium) } \\
\hline Low & $-0.017(.022)$ & $-0.006(.032)$ & $-0.025(.031)$ \\
\hline High & $-0.083(.036)^{\mathrm{c}}$ & $-0.076(.052)$ & $-0.090(.046)^{\mathrm{c}}$ \\
\hline
\end{tabular}

3. STRUCTURED AND UNSTRUCTURED ACTIVITIES

Structured activities:

Child engages in cultural activities (ref: no)

Yes

$0.099(.023)^{\mathrm{a}}$

$0.108(.032)^{\mathrm{a}}$

$0.085(.029)^{\mathrm{b}}$

Member of sports club/scouts/guides (ref: one)

Child member of both sport

$0.035(.030)$

$0.038(.046)$

$0.037(.040)$

club \& scouts/guides etc.

Child not member of either sport club

$-0.133(.025)^{\mathrm{a}}$

$-0.184(.046)^{\mathrm{a}}$

$-0.111(.030)^{\mathrm{a}}$ or scouts/guides

Unstructured activities:

Controlled Hours TV, Computer Usage, Video Games

More than $3 \mathrm{~h}$ /day TV

$-0.072(.033)^{\mathrm{c}}$

$-0.069(.050)$

$-0.074(.041)$ 
Table 7 (continued)

\begin{tabular}{lccc}
\hline & All & Boys & Girls \\
\hline $\begin{array}{l}\text { More than 1 h/day using } \\
\text { home computer }\end{array}$ & $0.060(.029)^{\mathrm{c}}$ & $0.063(.043)$ & $0.060(.040)$ \\
$\begin{array}{l}\text { More than 1 h/day } \\
\quad \text { video games }\end{array}$ & $-0.028(.026)$ & $-0.011(.032)$ & $-0.050(.042)$ \\
Activities with friends: (ref: 2-3 days/week) & & & \\
Never/1 day/week & $-0.003(.027)$ & $-0.018(.041)$ & $0.009(.034)$ \\
4-5 days/week & $0.066(.027)^{\mathrm{c}}$ & $0.094(.040)^{\mathrm{c}}$ & $0.042(.036)$ \\
6-7 days/week & $-0.045(.027)$ & $-0.008(.040)$ & $-0.087(.037)^{\mathrm{b}}$ \\
School Engagement (ref: likes school) & & & $-0.333(.071)^{\mathrm{a}}$ \\
Never likes school & $-0.252(.043)^{\mathrm{a}}$ & $-0.212(.052)^{\mathrm{a}}$ & 4,355 pupils in \\
$\mathrm{N}$ & 8,447 pupils in & 4,092 pupils in & 714 schools \\
& 881 schools & 724 schools & .131 \\
Pseudo R ${ }^{2}$ & .085 & .168 & \\
\hline
\end{tabular}

${ }^{\mathrm{a}} p<.001,{ }^{\mathrm{b}} p<.01,{ }^{\mathrm{c}} p<.05$

also seem that moderate levels of contact with friends during the week have a positive effect on mathematics scores, with those who engage in activities with friends 4-5 days per week achieving significantly higher mathematics scores than those with lower levels of engagement with friends. Finally, in the final block, children who respond that they never like school have significantly lower mathematics scores.

For the most part, these patterns hold for both males and females (Models 2, 3 of Table 7). It would appear that the effect of social class on mathematics attainment is stronger for boys than girls, however, as before, social, cultural and economic resources operate in the same way for males and females in terms of mathematics scores. The relationship between structured out-of-school activities and mathematics scores are similar for males and females - both appear to benefit from both cultural and sports/club activities. The main differences however, emerge in relation to time spent in unstructured activities out-of-school. Girls who spend more than 3 hours a day watching television have lower mathematics scores than girls who spend less time watching television $(p<.10)$, while no such effect exists for males. It would also seem that moderate levels of contact with friends during the week have a positive effect on mathematics scores for boys, with those who engage in activities with friends 4-5 days per week achieving significantly higher mathematics scores than those with lower levels of engagement with friends. Furthermore, intensive engagement with friends has a negative effect on mathematics attainment for females but not for males.

\section{Discussion and Conclusions}

In this paper, we consider the influence that participation in structured and unstructured activities has on school engagement and academic achievement. 
Guided by the conceptual work of concerted cultivation (Lareau 2003), we examine gender and social class differences in out-of-school activities and consider their effect on students' school engagement and academic achievement at age nine. Our findings suggest that both social class and gender make a difference in how parents raise children, particularly in terms of the structure of daily life: there is a clear social gradient in the uptake of structured activities (cultural activities, participation in organised clubs) and unstructured activities (watching television, using computers and video games, spending time with friends). In line with the conceptual work of Lareau (2003), practices associated with concerted cultivation (structured activities) tend to be more typical of middle class groups.

While previous studies have indicated that concerted cultivation practices are more pronounced among girls than boys (see for example Cheadle and Amato 2010), our findings suggest that girls and boys are more likely to participate in certain types of structured and unstructured activities rather than structured or unstructured activities per se. Our descriptive findings suggest that while childrearing logics tend to operate within social class categories, there is an additional cultural aspect of gender in the uptake of different types of structured and unstructured out-of-school activities. Furthermore, social class patterns do not always hold for males and females alike. Thus, our findings suggest the need to move beyond explanations of 'concerted cultivation' to explain how out-of-school activities influence school engagement and attainment for boys and girls.

Examining the role of gender, social class and structured and unstructured out-ofschool activities, the findings suggest that gender exerts an influence on attitudes towards school, independent of either social class or household income. Boys are more likely to report that they dislike school and social class differences are more pronounced among boys than girls. However, traditional concerted cultivation practices (structured cultural out-of-school activities) contribute to the greater school engagement of boys but not of girls; it appears boys have more to gain from participating in these activities. This means that although boys are less likely to participate in these activities, when they do, they are significantly more likely to be positively engaged towards school than boys who do not participate in these activities. Adopting structured activities/concerted cultivation practices normally associated with females has a positive effect on the attitudes of boys towards their schooling - 'playing female'. Furthermore, in line with the concerted cultivation argument, some unstructured out-of-school activities (videogames usage) are negatively related with school engagement, particularly for boys.

In terms of academic achievement, we find that gender exerts an influence on reading and mathematics attainment, independent of parental social class or parental income. Social class differences for boys and girls do not differ, as students from higher social class backgrounds have higher levels of reading and mathematics attainment, irrespective of gender. Traditional concerted cultivation practices (participation in cultural activities) exert a positive influence on reading and mathematics attainment for both boys and girls. However, participation in other structured and unstructured activities has differential effects for boys and girls in mathematics and reading. These findings lead us to suggest that the processes shaping attainment in mathematics are somewhat different to those underpinning reading attainment. 
Hence, although children's out-of-school time is often divided into structured and unstructured activities it would seem that the type of structured activities in which children engage influences school engagement. Perhaps structured activities can be further divided into activities associated with high and low financial costs. These findings show that participation in traditional concerted cultivation practices often associated with high costs appear to positively impact on reading and mathematics scores for boys and girls. As mentioned, participation in structured cultural activities has a particular impact on boys' school engagement. While overall participation in other low cost structured activities such as sports, scouts and guides has a positive relationship with academic achievement, girls particularly benefit from participation in such activities. Overall, the results highlight differences in the out-ofschool lives of boys and girls from different social backgrounds, and reveal important processes shaping and preserving social inequality in educational attainment. While research elsewhere has found that 'too much' or excessive demands being placed on children, or what has been termed the 'hurried child' effect, may hamper academic efforts and perhaps other aspects of children's wellbeing (Tofler et al. 1999; Rosenfeld and Wise, 2000; Postman, 1982), we find little evidence of this. In fact it could be argued that participating in a range of structured activities reinforces childrens' orientation towards, and learning at, school.

Acknowledgement Growing $U p$ in Ireland data have been funded by the Government of Ireland through the Office of the Minister for Children and Youth Affairs; have been collected under the Statistics Act, 1993, of the Central Statistics Office. The project has been designed and implemented by the joint ESRI-TCD Growing Up in Ireland Study Team. (C) Department of Health and Children

\section{References}

Archer, L., \& Francis, B. (2007). Understanding minority ethnic achievement. London: Routledge.

Banks, J., Byrne, D., McCoy, S., \& Smyth, E. (2010). Engaging young people? student experiences of the leaving certificate applied programme. Dublin: Economic and Social Research Institute.

Bernstein, B. (1975). Class, codes and control. Towards a theory of educational transmission. London: Routledge and Kegan Paul Ltd.

Bodovski, K., \& Farkas, G. (2008). "Concerted cultivation” and unequal achievement in elementary school. Science Direct, 37, 903-919.

Bourdieu, P. (1973). The three forms of theoretical knowledge. Social Science Information, 12, 5380.

Bowles, S., \& Gintis, H. (1976). Schooling in capitalist America. London: Routledge and Kegan Paul.

Broh, B. A. (2002). Linking extracurricular programming to academic achievement: Who benefits and why? Sociology of Education, 75, 69-96.

Bronfenbrenner, U. (1979). The ecology of human development: Experiments by nature and design. Cambridge: Harvard University Press.

Bronfenbrenner, U., Morris, P., et al. (2006). The bioecological model of human development. In R. M. V. Lerner, W. Damon, \& R. M. S. Lerner (Eds.), Handbook of child psychology, vol. 1: Theoretical models of human development (6th ed., pp. 793-828). Hoboken: Wiley.

Byrne, D. (2007). The influence of early work experiences undertaken before leaving second-level education on the socio-economic outcomes of school-leavers in the Republic of Ireland. PhD Diss (University of Edinburgh).

Byrne, D., \& Smyth, E. (2010). Behind the Scenes? A study of parental involvement in second level education Dublin: The Liffey Press in association with The ESRI, NCCA and Department of Education and Science. 
Cheadle, J. E. \& Amato, P. R. (2010). A quantitative assessment of Lareau's Qualitative Conclusions About Class, Race and Parenting, Journal of Family Issues http://soc.sagepub.com Published online October 21, 2010.

Cheevers, C., Doyle, O. \& McNamara, K. (2010). Child externalising and internalising behaviour in the first year of school: the role of parenting in a low SES population. Working Papers 201039. Dublin: University College Dublin.

Connolly, P. (2006a). Summary statistics, educational achievement gaps and the ecological fallacy. Oxford Review of Education, 32(2), 235-252.

Connolly, P. (2006b). The effects of social class and ethnicity on gender differences in GCSE attainment: a secondary analysis of the youth cohort study of England and Wales 1997-2001. British Educational Research Journal, 32(1), 3-21.

Corsaro, W. A. (1997). The sociology of childhood. Thousand Oaks: Pine Forge.

Elkind, D. (1981). The hurried child. Reading: Addison-Wesley.

Elkind, D. (2006). The hurried child. Reading: Addison-Wesley.

Epstein, D., Elwood, J., Hey, V., \& Maw, J. (Eds.). (1998). Failing boys? Issues in gender and achievement. Buckingham: Open University Press.

Educational Research Centre. (2007a). Drumcondra primary reading test—revised. Dublin: ERC.

Educational Research Centre. (2007b). Drumcondra primary mathematics test—revised. Dublin: ERC.

Fischbein, S. (1990). Biosocial influences on sex-differences for ability and achievement-test results as well as marks at school. Intelligence, 14(1), 127-139.

Fischbein, S., Lange, A. L., \& Lichtenstein, P. (1997). Quantitative genetic analyses of gender differences in educational and occupational careers. Scandinavian Journal of Educational Research, 41(1), 73-86.

Fletcher, A. C., Nickerson, P., \& Wright, K. L. (2003). Structured activities in middle childhood: links to well being. Journal of Community Psychology, 31(3), 641-659.

Francis, B. (1999). Lads, lasses and (New) labour: 14-16 year old student' responses to the 'laddish behaviour and boys' underachievement' debate. British Journal of Sociology of Education, 20, 357-373.

Francis, B. (2009). The role of the boffin as abject other in gendered performances of school achievement. The Sociological Review, 57(4), 645-669.

Francis, B., \& Skelton, C. (2005). Reassessing gender and achievement. London: Routledge.

Gillies, V. (2007). Marginalised mothers: Exploring working class experiences of parenting. Abingdon: Routledge.

Gorard, S., Rees, G., \& Salisbury, J. (1999). Reappraising the apparent underachievement of boys at school. Gender and Education, 11(4), 441-454.

Halpenny, A.M., Nixon, E. \& Watson, D. (2010). Parents' Perspectives on Parenting Styles and Disciplining Children. Dublin: Office of the Minister for Children and Youth Affairs.

Hays, S. (1996). The cultural contradictions of motherhood. New Haven: Yale UP.

Lareau, A. (2003). Unequal childhoods: Class, race and family life. Berkeley: University of California Press.

Marks, G. N., Cressell, J., \& Ainley, A. (2006). Explaining socioeconomic inequalities in student achievement: the role of home and school factors. Educational Research and Evaluation, 12(2), 105128.

Marsh, H., \& Kleitman, S. (2003). Consequences of sport participation in high school. Journal of Applied Sport Psychology, 25(2), 205-228.

McCoy, S., \& Smyth, E. (2007). So much to do, so little time: part-time employment among secondary students in Ireland. Work, Employment and Society, 21, 227-246.

McCoy, S., Quail, A. and Smyth E., forthcoming. Influences on Children's Learning: Home, School and Community.

McCoy, S. and Banks, J. forthcoming. Simply academic? Why children with special educational needs don't like school. (Under consideration for publication).

McCoy, S., Smyth, E., Darmody, M., \& Dunne, A. (2006). Guidance for All? Guidance provision in second-level schools. Dublin: Economic and Social Research Institute and Liffey Press.

McCoy, S., Byrne, D., O'Connell, P., Kelly, E., \& Doherty, C. (2010). Hidden disadvantage? A study of the Low participation in higher education by the Non manual group. Dublin: Economic and Social Research Institute.

McNeal, R. (1995). Extracurricular activities and high school dropouts. Sociology of Education, 68, 62-81.

McNeal, R. (1998). High school extracurricular activities: closed structures and stratifying patterns of participation. The Journal of Educational Research, 91, 183-191.

Mensah, F. K., \& Kiernan, K. (2010). Gender differences in educational attainment: influences of the family environment. British Educational Research Journal, 36(2), 239-260. 
O'Brien, M. (2007). Mothers' Emotional care work in education and its moral imperative. Gender and Education., 19(2), 159-178.

O'Brien, M. (2008). Gendered capital: emotional capital and Mothers' care work in education. British Journal of Sociology of Education, 29(2), 137-149.

O’Connor, M. (2007). SéSí gender in Irish education. Dublin: Department of Education and Science.

O'Hara, P. (1998). Partners in production? Women, farm and family in Ireland. Oxford: Berghahn Books.

OECD. (2007). PISA 2006. Science competencies for Tomorrow's world, volume 1 - analysis. Paris: OECD.

Phillips, J. C., \& Schafer, W. E. (1971). Consequences of participation in interscholastic sport. Pacific Sociological Review, 14, 328-338.

Posner, J. K., \& Vandell, D. L. (1999). After school activities and the development of Low income urban children: a longitudinal study. Developmental Psychology, 35(3), 868-879.

Postman, N. (1982). The disappearance of childhood. New York: Delacorte Press.

Power, T. G., McGrath, M. P., Hughes, S. O., \& Manire, S. H. (1994). Compliance and self-assertion: Young children's responses to mothers versus fathers. Developmental Psychology, 30, 908-989.

Rosenfeld, A., \& Wise, N. (2000). The over-scheduled child: Avoiding the hyper-parenting trap. New York: St. Martin's Press.

Scarr, S., \& Weinberg, R. A. (1994). Educational and occupational achievements of brothers and sisters in adoptive and biologically related families. Behavior Genetics, 24, 301-325.

Shonkoff, J. P., \& Philips, D. A. (2000). From neurons to neighborhoods: The science of early childhood development. Washington: Institute of Medicine.

Smyth, E. (1999). Do Schools Differ? Dublin: ESRI in assocation with Oak Tree Press.

Smyth, E., Whelan, C. T., McCoy, S., Quail, A., \& Doyle, E. (2010). Understanding parental influence on educational outcomes among 9 year olds in Ireland: the mediating role of resources, attitudes and Children's Own resources. Child Indicators Research, 3(1), 85-104.

Tofler, I. R., Knapp, P., \& Drell, M. J. (1999). The "achievement by proxy" spectrum: recognition and clinical response to pressured and high achieving children and adolescents. The Journal of the American Academy of Child and Adolescent Psychiatry, 38(2), 213-216.

Vincent, C., \& Ball, S. (2007). 'Making up' the middle-class child: families, activities and class dispositions. Sociology, 41(6), 1061-1077. 